\title{
Progress in development of Membrane Fouling Control for Microalgae Filtration: a Review
}

\author{
${ }^{1}$ Nik Nurul Ain Nabilah Razak, ${ }^{2 *}$ Muhammad Roil Bilad \\ ${ }^{1}$ Department of Chemical Engineering, Universiti Teknologi PETRONAS, 32610 Bandar Seri Iskandar, \\ Perak, Malaysia \\ ${ }^{2}$ Faculty of Science, Engineering and Applied Science, Universitas Pendidikan Mandalika, Jl. Pemuda \\ No. 59A, Mataram 83126, Indonesia \\ Corresponding Author email: muhammadroilbilad@ikipmataram.ac.id
}

Received: 20 March 2021; Revised: 30 March 2021; Published: 30 March 2021

\begin{abstract}
Microalgae biomass is an attractive feedstock for biofuels and other applications. Prior utilization the microalgae biomass must be harvested, a step that contributes largely to the overall energy and production costs. Membrane filtration is seen as a viable option for microalgae concentration. It is mainly attractive as primary step treating the diluted broth. However, its application is largely limited by membrane fouling that lowers overall process efficiency and productivity. This study provides an overview on the recent progress of the membrane development particularly on technology to address the tmembrane fouling issue in microalgae filtration and upconcentration. Firstly, brief introduction of potential of microalgae biomass and membrane technology is provided. It followed by comprehensive overview of membrane fouling control approach. The membrane fouling control approaches are classified into optimization of operational parameters, membrane material development, hydrodynamic manipulation, improved module design and lastly module spacer development. Lastly, perspective on future research direction is also provided.
\end{abstract}

Keywords: microalgae harvesting; membrane filtration; membrane fouling; biofuel; renewable energy

How to Cite: Razak, N., N., A., N., \& Bilad, M., R. (2021). Progress in development of Membrane Fouling Control for Microalgae Filtration: a Review. Jurnal Penelitian dan Pengkajian Ilmu Pendidikan: $e_{-}$ Saintika, 5(1), 67-91. doi:https:/ / doi.org/10.36312/e-saintika.v5i1.424

https://doi.org/10.36312/e-saintika.v5i1.424

\section{INTRODUCTION}

Attempts to explore sustainable sources for energy source have been increasing to counter the inevitable issue of depleting resources and detrimental environmental impacts of fossil fuels combustion. Biomass based in microalgae is seen as one potential feedstock for biofuels and feeds (Maeda et al., 2018). Microalgae have favorable characteristics, to name but few fast growth rate, high content of lipid that make them very attractive as a biofuels feedstock (Qari et al., 2017; Yanfen et al., 2012). Nonetheless, the issue of high energy consumption during biomass harvesting from the growth medium still need to be resolved to realised its potential.

To convert microalgae biomass to biofuels, it has to undergo few steps: cultivation, harvesting, and oil extraction ( $\mathrm{Su}$ et al., 2017). Among all steps, the biomass harvesting consumes the highest energy; and $90 \%$ of the costs are invested 
on the harvesting and the dewatering processing units (Amer et al., 2011). Due to energy-intensive nature of biomass harvesting process, it contributes to $20-30 \%$ of the operational cost of overall biomass cultivation, harvesting and pre-processing (Mata et al., 2010; Molina Grima et al., 2003; Verma et al., 2010). Beilen (2010) also mentioned that $25-75 \%$ of the total energy is consumed in the cultivation and harvesting processes. Therefore, commercialization of microalgae to biofuels by implementing the current technologies becoming economically unfeasible (Singh \& Patidar, 2018). Energetically, substantial reduction in energy input for biomass processing is still required. Research on finding the suitable and energy-efficient harvesting method should then be targeted.

Attributes of microalgae that can convert sun light and inorganic carbon (i.e., carbon dioxide) into useful biomass and incorporating nutrients make them attractive to be converted into crude oil. When aimed for biofuels end-products, the lipid extraction yield need to be maximized and done in the most economical ways. Adopting recently developed techniques can result in a high lipid extraction yield even from biomass with lipid content of as low as 10\% (Bharathiraja et al., 2015). Few microalgae species, such as Chlorella vulgaris and C. emersonii have been demonstrated in large tubular photobioreactorunder a nutrient concentration (Scragg et al., 2002). The highest energy content was shown by $C$. vulgaris under low nitrogen concentration in the growth medium. Recent reports on the microalgae species aimed for biofuel end-products were done using the following species: Chlorella sp., specifically C. emersonii, C. minutissima, C. vulgaris and C. protothecoides. Chlorella sp.. Those species could produce biomass with up to $63 \%$ lipid content (Illman et al., 2000).

Various methods have been proposed for harvesting microalgae. They are filtration, centrifugation, flocculation, sedimentation or a combination thereof (Milledge \& Heaven, 2013). Each of these methods has respective advantages and drawbacks. Flocculation method requires additional chemicals as flocculant, which contribute to another additional cost for harvesting and it is difficult to separate coagulant from the harvested microalgae. However, contamination of microalgae could happen when using bio flocculation method. A method using an electrical base coagulation (electrocoagulation-flocculation) has also proven very costly (Barros et al., 2015). Centrifugation is highly efficient but expensive. It may destruct the microalgae cell due to high shear forces in the medium (Singh \& Patidar, 2018).

Membrane filtration is seen as promising technological option for preconcentration of microalgae biomass from the growth medium. It offers low energy input, complete biomass retention, good scaleability, and require low quantity of chemicals only for membrane cleaning when required, etc. (Eliseus et al., 2017). Nonetheless, the implementation of membrane based process is highly limited by membrane fouling, which motivates researcher to develop membrane material, operational methods and new module design as options to control membrane fouling. Recent developments on method and approach for membrane fouling control for microalgae harvesting were critically reviewer in this report.

\section{MICROALGAE SPECIES AND BIOMASS DERIVATIVES}

Around $87 \%$ of global $\mathrm{CO}_{2}$ emision is originated from activities related to combustion of natural gas, fuels and coal (Raheem et al., 2018). Hence, one simple way 
to reduce the carbon emission is by replacing those fuels with renewable resources that are proven to lower the carbon footprint. Biomass has already become one of the most attractive resources for bioenergy and bioproducts. Many forms of biomass products have been used as energy source, such as wood, agricultural residues, microalgae and non-edible energy crops (Raheem et al., 2018).

Microalgae have recently been exploited widely as potential supply of usable biomass feedstock. Microalgae biomass becomes significant because it contains high amount of lipids and the cell grows rapidly (Qari et al., 2017). It makes them attractive economically and time wise as they can offer much higher yield and faster growth rate than the traditional crops and can be cultivated even in wastewater. Microalgae are unicellular and thus do not require cellulose for roots and stems thus easily processed (Qari et al., 2017). The microalgae do not necessarily requiring fertile land because of their persistence to grow in wastewater or seawater (Raheem et al., 2018).

Microalgae have variable metabolisms: heterotropic and autotropic. The autotropic ones use inorganic carbon as as the carbon source. The photoautotrophic use light as energy source; while the heterotrophic use organics as the source of carbon (Qari et al., 2017). Under limited nitrogen or high light conditions during cultivation, their neutral lipid content in the biomass increases significantly, that make them attractive as feedstock of biofuels. More light during cultivation also lead to high production of lipid. However, excessive light can be harmful due its detrimental effect that leads to susceptibility to photo-oxidative stress. Table 1 compares biomass produced by different types of microalgae species. It proves that various species of microalgae could be converted into biomass. However, these microalgae are cultivated using different culture and nutrients.

Table 1. Microalgae species explored for biofuel production

\begin{tabular}{|c|c|c|c|}
\hline Species & $\begin{array}{l}\text { Biomass } \\
\text { yield }(g / 1 / d)\end{array}$ & $\begin{array}{l}\text { Lipid yield } \\
(\mathrm{g} / \mathrm{l} / \mathrm{d})\end{array}$ & Reference \\
\hline Botryococcus braunni & 0.16 & $0.03-0.06$ & (Kalacheva et al., 2002) \\
\hline Chaetoceros calcitrans & $\mathrm{N} / \mathrm{A}$ & 0.022 & (Natrah et al., 2007) \\
\hline Chlorella emersonii & $0.25-0.36$ & $0.122-0.157$ & $\begin{array}{l}\text { (Illman et al., } \\
\text { 2000),(Scragg et al., 2002) }\end{array}$ \\
\hline Chlorella minutissima & 0.16 & 0.091 & (Illman et al., 2000) \\
\hline Chlorella vulgaris & $0.24-0.37$ & $0.148-0.14$ & $\begin{array}{l}\text { (Illman et al., 2000; } \\
\text { Scragg et al., 2002) }\end{array}$ \\
\hline Chlorella protothecoides & $0.93-1.3$ & $0.56-0.654$ & $\begin{array}{l}\text { (Shen et al., 2010; Xu et } \\
\text { al., 2006) }\end{array}$ \\
\hline Isochrysis galbana & $\mathrm{N} / \mathrm{A}$ & 0.0207 & (Natrah et al., 2007) \\
\hline Nannochloropsis sp. & $0.09-0.48$ & $0.025-0.142$ & $\begin{array}{l}\text { (Chiu et al., 2009; Rodolfi } \\
\text { et al., 2009) }\end{array}$ \\
\hline Neochloris oleoabundans & $0.055-0.09$ & $0.0126-0.0261$ & $\begin{array}{l}\text { (Chiu et al., 2009; Rodolfi } \\
\text { et al., 2009) }\end{array}$ \\
\hline $\begin{array}{l}\text { Schizochytrium } \\
\text { limacinum }\end{array}$ & $0.186-2.0$ & $0.22-0.54$ & $\begin{array}{l}\text { (Chin et al., 2006; Liang } \\
\text { et al., 2014) }\end{array}$ \\
\hline Scenedesmus obliquus & 0.15 & 0.27 & $\begin{array}{l}\text { (Mandal \& Mallick, } \\
\text { 2009) }\end{array}$ \\
\hline
\end{tabular}


Figure 1 show the conventional steps to convert microalgae into biofuels. Microalgae firstly need to be produced in the cultivation step. Light, carbon dioxide, water and nutrients need to be present at suitable temperature in microalgae production (Demirbas \& Demirbas, 2010). Then, the biomass needs to be harvested by removing water from the growth medium after cultivation in an open raceway pond or membrane photobioreactor (MPBR). In the following step, the oil content is extracted using chemical extraction method. The extracted oil is then converted into fuel through acid/base catalysis process called transesterification. Finally, series of separation are needed to separate the products from unconverted biomass (Demirbas \& Demirbas, 2010).

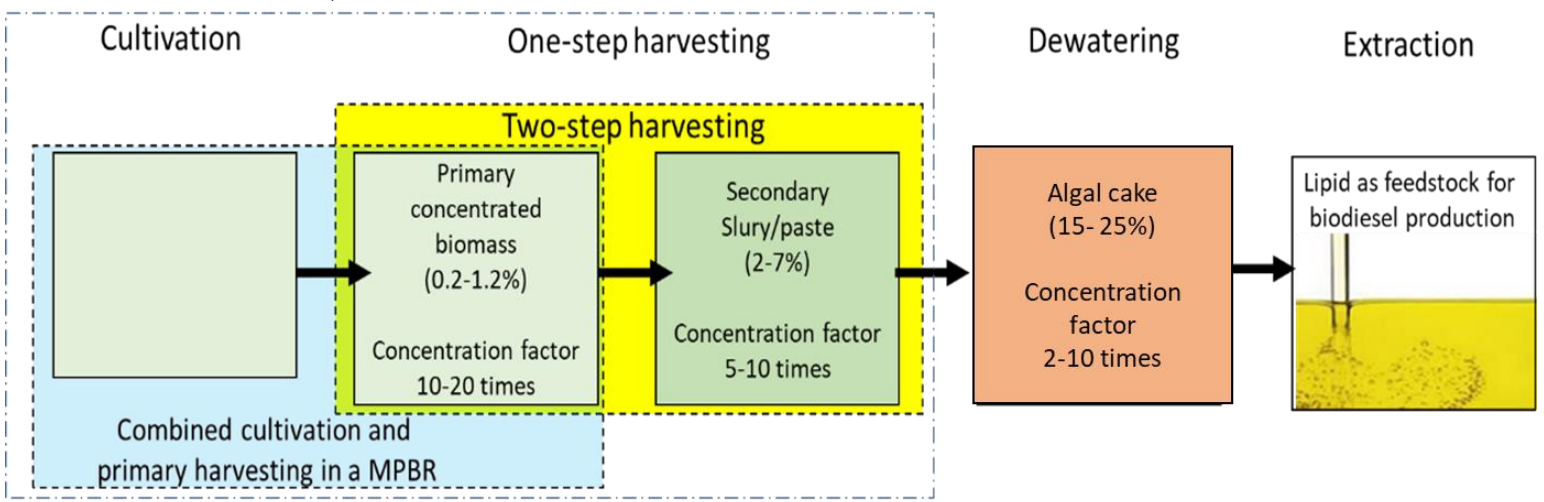

Figure 1. The steps for production of lipid as biofued feedstock starting from microalgae cultivation.

Microalgae harvesting refer to the process of concentrating biomass from the the cultivation medium to a concentration feasible for subsequent operation. Microalgae harvesting is also defined as the detachment of algae from its medium (Singh \& Patidar, 2018). Dewatering microalgae are very costly which consume $20-30 \%$ of the cost from the overall biofuels production. Various method can be used to harvest microalgae from its medium such as centrifugation, (bio)-flocculation, filtration or any hybrid process of these method (Milledge \& Heaven, 2013). Table 2 summarize the harvesting technologies available and the possible costs of each harvesting method.

Table 2. Summary of microalgae harvesting technologies

Filtration Cost of biomass harvesting spend on the membrane fabrications. As this method could give high biomass recovery. Besides membrane can varies its pore size make it convenient to harvest various type of microalgae species.

Centrifugation Centrifugal forces needed to harvest microalgae. This separation process requires time and energy to get the harvested biomass.

Flocculation Flocculation method is a method that use flocculants that will floc cells together. However, the excessive use of the flocculent is not eco-friendly further treatment required and increase the production costs.

Flotation Flotation unit generates fine bubbles that can adhere to the microalgae cells to lower the overall density less that the water density and allow it to float for easy harvesting. It is considered as 
high cost due to power consumption and the cost for of the flocculent chemicals.

Extraction of Ionic liquid is still very expensive and only explored in lab-scale. bioproducts

from

microalgae

using ionic

liquids

\section{MEMBRANE TECHNOLOGIES FOR MICROALGAE HARVESTING}

Membrane-based microalgae filtration is an established process widely used for liquid, gas and multi-phase separation (Castel \& Favre, 2018). Bilad et. al. (2012) report the advantages of membrane separation for microalgae harvesting. They found that membrane process offers continuous separation, simple operation and low energy foot-prints. Besides, they also highlight flexibility of membrane process to be combined with other systems to form a hybrid process (process intensification). Membrane system can also be easily scaled up. Those advantages lead to offer application of membrane technology as attractive process in harvesting microalgae, especially for the initial stage of concentration, that handles a more diluted broth.

Materials used to prepare membrane for microalgae harvesting are mostly organic or polymeric. They are mostly ultrafiltration (UF) and microfiltration (MF), which already offer almost full rejection of microalgae biomass (Bilad et al., 2012). High biomass rejection is attributed to size exclusion due to relatively much smaller membrane pore in comparison to the size of the microalgae cell. However, membrane process is strongly limited by membrane fouling. Membrane fouling degrades permeance of the membrane and reduces the separation efficiencies. Attempt on excessive control membrane fouling chemically may lead to low life span of the membrane (Bilad et al., 2012) because of the cleaning chemicals that can degrade the membrane material.

Depending on the ability to reject certain compound(s), pressure driven membranes can be classified into reverse osmosis (RO), nanofiltration (NF), UF and MF. Two main parameters determine filtration performance: flux (J) or permeability $(\mathrm{L})$ and rejection $(\mathrm{R})$. Membrane materials are shaped into vrious types of module to allow filtration process. Yypical modules for pressure driven membrane are (multi)tubular (MT), plate-and-frame (FS), capillary tube, hollow fiber (HF), and spiral wound.

There are two ways to run a filtration: cross flow or dead-end. For the latter, the pressurized feed is pumped through the feed side of the membrane or by creating vacuuming the permeate side. For the former, the feed is pumped tangentially creating a crossflow along the membrane surface. Both dead-end and cross-flow systems can be operated at a constant transmembrane pressure (TMP) or a constant flux modes.

In microalgae harvesting context, the system can be run either using constantflux or constant pressure operation. The constant pressure is only applicable when the feed is constituted by a pure solvent. In a constant flux operation, the TMP often increases dramatically during the filtration, especially when the feed contains 
suspended material of macromolecules. This is a result of build-up foulant, forming cake or biofilm layer on the membrane surface. All of those cause a loss of a membrane permeability in general referred to as membrane fouling.

To maintain the membrane long-term performance, the filtration is normally done in cycles, involving relaxation or backwash, maintenance and intensive chemical cleaning. Another method to control fouling is by interrupting or disturbing the foulant using the shear-rate due to high crossflow velocities or a secondary flow, or by applying dynamic filtration system (DFS).

In the context of membrane process for microalgae harvesting, microalgae cells are retained by the membrane for thickening the algae cultures. The water is removed as permeate to achieve this purpose. This process can be run in continuous, or batch mode depends on the membrane process design (Singh \& Patidar, 2018).

\section{MEMBRANE FOULING IN MICROALGAE FILTRATION}

Membrane fouling is defined as accumulation of materials on the membrane surface that deteriorates filtration performance. When fouling occur, permeability of the membrane decreases over time. This is because over the filtration time, the foulant accumulates and the more abundant of foulant is deposited on the surface. Membrane fouling becomes a big challenges to the separation process as it lower down the life span of the membrane, reduce the effectiveness of the separation process, increase energy requirement to operate the membrane and increase operational cost for the replacement of membrane. Membrane fouling is cause by the adsorption on the surface of the membrane (Abid et al., 2017). Therefore, membrane fouling control has become the main focus for many studies (Bilad, Marbelia, et al., 2014).

The foulant can accumulate to form a foulant layer (referred as 'cake layer') that cover the membrane surface. The cake layer is built up from microalgae cells, extracellular polymeric substances. This layer blocks the passage of the liquid to pass through the membrane. Thus, low rate of permeate can pass through the membrane. Because of membrane fouling, over a prolonged filtration time, a system operating under constant flux will lead to an increase in pressure and a system operating under constant pressure leads to flux decline.

Membrane fouling are caused by the adsorption of the solids, interaction of electrostatic forces between solids and biofouling that lead to precipitation of salts and other organic matter that block the membrane pores. Main challenge is to deal with biofouling because it block the membrane pores and promoting other fouling to occur (Hausman et al., 2009) such as salt and organic matter. Organic foulant will interact and becoming part of the cake layer.

\section{MEMBRANE FOULING CONTROL IN MICROALGAE HARVESTING}

Membrane fouling control is an effort to reduce the severity of fouling on the surface of the membrane. Since membrane fouling reduce the performance of the membrane, the ability to manage fouling ensure a more sustained operation (Eliseus et al., 2017). In this section, various approaches related to the topic of this thesis for membrane fouling control are discussed. 


\section{Optimization of operational parameter}

The most common method for membrane fouling control is to apply crossflow, enhanced by introduction of air bubbles. In the harvesting of microalgae, air bubbles and the cross flow are used to provide shear forces to remove foulant on the surface of the membrane (Bilad, Arafat, et al., 2014). In a submerged module system, the shearrate is generated by feed recirculation and by introducing coarse air bubbles (Bilad, Arafat, et al., 2014).

\section{Membrane development}

Another approach to reduce the membrane fouling propensity is by development of fouling resistant membrane materials. Table 3 summarizes recent reports on membrane development to improve fouling control in microalgae filtration. Membrane fabrication parameter optimizations such as concentration of polymer, time gap between casting and coagulation during the phase inversion, usage of the solvent and the additive during preparation of the membrane modules have been taken into considerations to customized the membrane properties suitable for microalgae filtration (Discart et al., 2015). Membrane prepared from low polymer concentration with polyvinylpyrrolidone additive at 3-5\% showed better performance than the $0-1 \%$ additive. This findings shows that high polymer concentrations result in low pores size and the membrane become unstable (Discart et al., 2015). Additional of water into the polymer solution increases the pore size from 0.087 to $0.143 \mu \mathrm{m}$ (Discart et al., 2015). Longer gaps between casting, low concentration of the polymer, adding water and additive during preparation of membrane can produce membrane with high porosity and thus improves the filterability of microalgae medium.

Fouling propensity of membrane material can be reduced by manipulating these 3 parameters; 1) zeta potential, 2) hydrophilic density of the surface and the 3) contact angles of the membrane (Hwang, Kotte, et al., 2015). PVDF-based membrane with PEGylated PEI particles and Pluronic F-127 additive (PNSM-1) offers a complete biomass retention with a permeate flux of $96 \mathrm{~L} / \mathrm{m}^{2} \mathrm{~h}$ that is larger (by $\sim 50 \%$ ) than that of a commercial and hydrophilic PVDF UF membrane used as reference (Hwang, Kotte, et al., 2015).

Hydrophilic membrane materials offer improved microalgae filterability (Marbelia et al., 2018). They suggest using polyvinylpyrrolidone (PVP) modification and sulfonation to improve the hydrophilicity of the membrane. They have proven that hydrophilic property can improve the fouling control to the membrane as it reduces the interaction force between the membrane material and the solute (i.e., microalgae cell, algogenic organic matters, etc.). They also found out that the permeance increased only for the PVP-modified membranes that having lower contact angle. Solute interactions reduce by using hydrophilic particle in the membrane casting process (Marbelia et al., 2018). Hydrophilic particles favor water and reduce the adhesive force of the solids on the membrane surface, thus, increases the membrane permeability.

Venault et. al. (2016) reported that membranes made using vapor-induced phase separation process separation (VIPS) had low biofouling propensity. The hydrophilicity of poly(styrene)-b-poly(ethylene glycol) methacrylate (PS-b-PEGMA) was higher than the conventional PVDF membrane. PS-bPEGMA-4 has the highest 
water contact angles of $122^{\circ}$, but it had the best flux compare to the virgin membrane with angles of $188^{\circ}$ (Venault et al., 2016). They found that membrane with $4 \%$ of copolymer (PS-bPEGMA-4) had the lowest protein adsorption properties and thus high resistance on biofouling, which made the solute was less adhesive to the membrane surface. Though the resulting PVDF membrane had amphiphilic properties, the hydration capacity, protein adsorption properties of PS-b-PEGMA and bacteria resistance turned the membrane to achieve high permeance compare to the pristine membrane.

The membrane porosity can affect the cake formation (Marbelia et al., 2016). Hence, authors study on the comparisons of polyacrylonitrile (PAN) membrane with different porosity and the membrane with low porosity have higher clean water permeance (CWP). Low polymer content in the membrane promote better porosity which can be seen at PAN-8 $\left(580 \mathrm{~L} / \mathrm{m}^{2} \mathrm{~h}\right.$ bar) and PAN-13 $\left(60 \mathrm{~L} / \mathrm{m}^{2} \mathrm{~h}\right.$ bar $)$ in 35 minutes filtration of Chlorella vulgaris (Marbelia et al., 2016). Negatively charged membrane on polyacylanitrile had treated by hydrolysis (PAN-H) could reduce fouling caused by electrostatic effect between negative charge of alga organic matter (AOM) and the negative charge of the membrane during the earlier fouling (Marbelia et al., 2016). They found that PAN-H membrane at $\mathrm{pH} 4$ had negative charge on the membrane surface thus increased the hydrophilicity of the membrane though the CWP showed that the size of the pores decreases. The electrostatic effect in the filtration process depended on the zeta potential of the microalgae. Negatively charge membrane provided repulsion effect to the high zeta potential cells.

Table 3. Summary of the literature on membrane development to improve fouling control in microalgae filtration

\begin{tabular}{|c|c|c|c|}
\hline Fabrication parameters & Performance & Remarks & Reference \\
\hline $\begin{array}{l}\text { Exploring the impact of } \\
\text { time gap } \\
\text { Concentration of } \\
\text { polymer and water as } \\
\text { non-solvent additive in } \\
\text { dope solution }\end{array}$ & $\begin{array}{l}\text { The permeance } \\
\text { increase as an increase } \\
\text { in the time gaps (15- } \\
600 \text { s) due to an } \\
\text { increase in increase } \\
\text { pore size ( } 0.13 \text { to } 0.16) \text {. } \\
\text { Higher polymer } \\
\text { concentration leads to } \\
\text { lower pores size. Low } \\
\text { polymer with additive } \\
\text { of }(3-5 \%) \text { better than } \\
(0-1 \%) .\end{array}$ & $\begin{array}{l}\text { Pore size of } \\
\text { membrane range } \\
(0.08-0.17 \mu m \\
\text { (biomass fully } \\
\text { recovered } \\
\text { because biomass } \\
\text { sizes range from } \\
\text { 2-10 } \mu m \\
\text { Bigger pore size } \\
\text { gives low } \\
\text { hydraulic } \\
\text { resistance with } \\
\text { better flux. Bigger } \\
\text { pore size allows } \\
\text { more water pass } \\
\text { through. }\end{array}$ & $\begin{array}{l}\text { (Discart et } \\
\text { al., 2015) }\end{array}$ \\
\hline $\begin{array}{l}\text { Embedded hydrophilic } \\
\text { particle (Pluronic F-127, } \\
\text { polyvinylpyrrolidone }\end{array}$ & $\begin{array}{l}\text { A PVDF and } \\
\text { PEGylated PEI } \\
\text { particles and Pluronic } \\
\text { F-127 blend membrane }\end{array}$ & $\begin{array}{l}\text { Hydrophilic } \\
\text { properties help to } \\
\text { increase permeate } \\
\text { of the membrane. }\end{array}$ & $\begin{array}{l}\text { (Hwang, } \\
\text { Kotte, et } \\
\text { al., 2015) }\end{array}$ \\
\hline
\end{tabular}




\begin{tabular}{|c|c|c|c|}
\hline Fabrication parameters & Performance & Remarks & Reference \\
\hline $\begin{array}{l}\text { and polyethylene glycol } \\
\text { as additive) }\end{array}$ & $\begin{array}{l}\text { retained fully the } \\
\text { biomass at high flux } \\
\left(96 \mathrm{~L} / \mathrm{m}^{2} \mathrm{hr}\right) \text {. }\end{array}$ & $\begin{array}{l}\text { PEGylated PEI } \\
\text { particles has high } \\
\text { hydrophilic } \\
\text { attributes. }\end{array}$ & \\
\hline $\begin{array}{l}\text { PVP as additive to for } \\
\text { favorable membrane }\end{array}$ & $\begin{array}{l}\text { For the PVP-modified } \\
\text { membranes, contact } \\
\text { angle values decrease } \\
\text { resulting higher } \\
\text { permeance. }\end{array}$ & $\begin{array}{l}\text { Hydrophilic } \\
\text { particles favor } \\
\text { water and reduce } \\
\text { the adhesivity of } \\
\text { the solids on the } \\
\text { membrane } \\
\text { surface. }\end{array}$ & $\begin{array}{l}\text { (Marbelia } \\
\text { et al., } \\
\text { 2018) }\end{array}$ \\
\hline $\begin{array}{l}\text { Application of vapor } \\
\text { induced phase } \\
\text { separation for } \\
\text { membrane fabrication }\end{array}$ & $\begin{array}{l}4 \mathrm{wt} \% \text { copolymer (PS- } \\
\text { bPEGMA-4) have the } \\
\text { best flux because of its } \\
\text { higher hydration } \\
\text { capacity of } 533 \pm 20 \\
\left(\mathrm{mg} / \mathrm{cm}^{3}\right) \text {, low protein } \\
\text { adsorption and high } \\
\text { resistance to bacteria } \\
\text { adhesion. }\end{array}$ & $\begin{array}{l}\text { The hydration } \\
\text { capacity, protein } \\
\text { adsorption } \\
\text { properties of PS- } \\
\text { b-PEGMA and } \\
\text { bacteria } \\
\text { resistance } \\
\text { increases } \\
\text { permeance } \\
\text { compare to the } \\
\text { virgin membrane. }\end{array}$ & $\begin{array}{l}\text { (Venault } \\
\text { et al., } \\
\text { 2016) }\end{array}$ \\
\hline $\begin{array}{l}\text { Addition of electrostatic } \\
\text { effect between the } \\
\text { organic matter and the } \\
\text { membrane }\end{array}$ & $\begin{array}{l}\text { Nutral or negatively } \\
\text { charged membranes } \\
\text { showed full biomass } \\
\text { retention since } \\
\text { microalgae has zeta } \\
\text { potential charges. Low } \\
\text { polymer content in the } \\
\text { membrane promote } \\
\text { better porosity can be } \\
\text { seen at PAN- } 8 \text { ( } 580 \\
\left.\mathrm{~L} / \mathrm{m}^{2} \mathrm{hbar}\right) \text { and PAN- } \\
13 \text { ( } 60 \mathrm{~L} / \mathrm{m}^{2} \mathrm{~h} \text { bar) in } \\
35 \text { minutes filtration of } \\
\text { chlorella }\end{array}$ & $\begin{array}{l}\text { The electrostatic } \\
\text { effect in the } \\
\text { filtration process } \\
\text { depends on the } \\
\text { zeta potential of } \\
\text { the microalgae. } \\
\text { Negatively } \\
\text { charge membrane } \\
\text { gives repulsion } \\
\text { effect to the high } \\
\text { zeta potential } \\
\text { cells. }\end{array}$ & $\begin{array}{l}\text { (Chiu et } \\
\text { al., 2009) }\end{array}$ \\
\hline
\end{tabular}

\section{Hydrodynamic engineering}

Table 4 summarizes dynamic membrane systems for fouling control in microalgae harvesting. Dynamic membrane system employs mechanical movements to promote mixing and turbulence, hence helps to reduce membrane fouling by improving mass transfer rate of the fluid.

Bilad et. al. (2013) applied a magnetically induced membrane vibrations (MMV) for fouling control in microalgae harvesting. In the MMV system, membrane panel connects to a device that allows the membrane panel to vibrate. Vibration 
promotes the shear stress between the liquid and the membrane surface and thus helps scour-off the fouling on the membrane. MMV system offers a relatively low

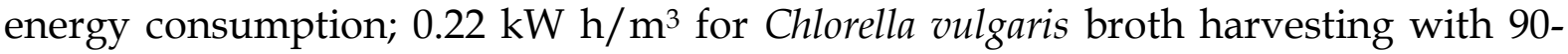
$100 \%$ filtration efficiency. They also mentioned that the MMV system enable the shear stress to only experience by the liquid-membrane interface and the remaining bulk liquid not affected with the shear stress forces. Thus, this can minimize the energy input. Vibration in submerged filtration system have low energy consumption due to the interaction occurs only at the membrane surface and the liquid only. The membrane surface-liquid occurs due to the high shear rates produces from the vibration system.

Zhao et al. (2016a) reported that axial vibration membrane can effectively reduce the fouling on the membrane. However, the studies show that the fouling on the membrane could not be remove by using vibration force as the attractive force bigger than the lift force. They also mentioned that when the microalgae cells had form bigger cell in the tank, it can be removed with the vibration hence, cake layer cannot be formed. Membrane fouling can be reduced by increasing the vibration rate at 10 $\mathrm{Hz}$. There was almost no algae depositing from the permeate of $40 \mathrm{~L} / \mathrm{m}^{2} \mathrm{~h}$ bar compare at $0 \mathrm{~Hz}$ only $15 \mathrm{~L} / \mathrm{m}^{2} \mathrm{~h}$ bar (Zhao, Chu, Tan, Yang, et al., 2016). Adsorption of extracellular organic matter on the membrane also decrease with the increment of the vibration frequency. Axial motions in the system hinder adhesion of the foulant to stick on the membrane surface.

Kanchanatip et al. (2016) proposed to build disc-typed membrane for ultrafiltration membrane. In this study, they use aeration bubbles from the tube as a way for membrane fouling control. Vibrated membrane systems have proven to give better permeance. However the fouling still occur on the surface of the membrane (Bilad, Marbelia, et al., 2014). They suggest effective chemical can improve the fouling control on the membrane surface. There are also comparison studies made by Zhao et al. (2016c) between axial vibration membrane (AVM) system and submerged aerated membrane (SAM) system which proved foulant are hardly found on AVM system compared to SAM system. Another way to reduce fouling to use axial vibration membrane which can increase the shear rates of the membrane (Zhao, $\mathrm{Chu}$, Su, et al., 2016). The fouling can be removed with the inertia cause by the axial movement.

(Armbruster et al., 2018) proposed to add turbulence promoters in the flow channel of the tubular flow to increase the shear rates and hence membrane fouling control. The 3D printing technology allows ones to vary the geometries of the promoters and enables them to improve the fouling control on the membrane surface. The highest flux improvement of $140 \%$ can be reached by applying a Kenics mixer. 3D printed promoters had promoted turbulence in the flow by designing promoters that can produce high turbulence fluid. Turbulence flow increase the shear rates on the membrane from the feed flow in the medium.

Another proposed method to control fouling is by induce ventilation or aeration into the module system. The air bubbles act as the cleaning agent by scrubbing the deposited solid on the membrane surface. This method seems convincing as $60 \%$ of flux recovery (Chen et al., 2012). Besides other study found out highest flux of $20.05 \mathrm{~L} \mathrm{~m}^{-2} \mathrm{~h}^{-1}$ can be achieved at aeration rate of $2.5 \mathrm{~L} / \mathrm{min}$ when compared with aeration only $11.16 \mathrm{~L} \mathrm{~m}^{-1} \mathrm{~h}^{-1}$ (Alipourzadeh et al., 2016). Furthermore, 
aeration helps the microalgae become thicker up 5.4 times in size compare to the initial size. This reduces the tendency for the particles stick to the membrane surface as it becomes heavier.

Intermittent ventilation also observed to affect the flux. Shorter intermittent time (10 minutes) was better than longer intermittent time (10 minutes) as the cake formation was compressed in between the 20 minutes gap make the foulant hard to remove (Chen et al., 2012). Reversible fouling are absent in both aeration and vibration model prove this system can slow down and reduce the layer of foulant on the membrane (Bilad, Marbelia, et al., 2014). Air bubbles were applied as the cleaning method to the membrane. They scour off the reversible fouling on the membrane. High aeration rate provides more bubbles and gives better flux.

Recent study showed that an improvement in the hydrodynamic condition of the filtration medium (such as via vibration in the medium) can increase shear rates, as well as the filtration permeance (Bilad et al., 2013). By adopting the same principle in inducing hydrodynamics, Zhao et al. (2016a) uses axial vibration membrane system to clump the algae particles, as such the biomass does not penetrate the membrane pores to enhance filtration permeance. Some modules use rotational and tangential forces to increase the shear rates and turbulent during the filtration system to also effectively increase the filtration permeance (Frappart et al., 2011). These reports collectively support the efficacy of the hydrodynamics in increasing filtration permeance.

Air bubble scouring has been widely accepted as a standard physical cleaning method for porous pressure driven membrane process (Bilad et al., 2012), especially in submerged filtration system. Air bubbles reduce the rate of foulant deposition by scouring-off the deposited foulant or by prevent its accumulation within pore or on the membrane surface. In the traditional plate and frame membrane panel configuration, plate-and-frame panels are arranged vertically with certain gaps to form a flow channel through which air bubble and liquid feed stream are flown. The two-phase flow of air in the feed liquid promotes turbulence and increases shear-rate that beneficial for foulant removal. In many newly developed systems for membrane fouling control, such basic arrangement is maintained and additional process is included to enhance the system efficiencies (i.e.,panel rotation,vibration,tilting, etc.)

Conventional spacers for membrane are typically used in a traditional spiral wound to increase mass transfer of the fluid and allow the space for liquid flow. On top of those, advance roles of spacer have been recently developed (Abid et al., 2017; Araújo et al., 2012; Li et al., 2016; Jianxin Liu et al., 2015; Jiuqing Liu et al., 2013; Yang et al., 2009). Coating of the spacers by the metal can help to induce biocide effect to limit development of biofouling on the membrane surfaces (Frappart et al., 2011; Zhao, Chu, Tan, Yang, et al., 2016). The geometry of the spacers can be manipulated to induce turbulence effect near by the membrane surface and which help to scour-off the foulant, i.e., by incorporating hairy structures attached on the spacers filaments (Li et al., 2016). Net typed spacers increase the shear rates and mass transfer properties in the filtration process (Abid et al., 2017). Custom 3D printed spacers have also recently explored to maximize the spacer roles in enhancing filtration performance (Siddiqui et al., 2016). In the traditional plate-and-frame panels, no spacer is required because the flow channel is created by leaving gap between adjacent panels. However, 
looking into the advanced role of the spacer in the spiral wound module, similar approach can be adopted for the plate-and-frame modules.

Table 4. Dynamic membrane system for fouling control

\begin{tabular}{|c|c|c|c|}
\hline $\begin{array}{l}\text { Dynamic } \\
\text { Membrane } \\
\text { system }\end{array}$ & Performance & Remarks & Reference \\
\hline $\begin{array}{l}\text { Magnetically } \\
\text { induced } \\
\text { membrane } \\
\text { vibrations } \\
\text { (MMV) }\end{array}$ & $\begin{array}{l}\text { MMV system offers a } \\
\text { relatively low energy } \\
\text { consumption; } 0.22 \mathrm{~kW} \\
\mathrm{~h} / \mathrm{m}^{3} \text { (Chlorella } \\
\text { Vulgaris). This } \\
\text { filtration has } 90-100 \% \\
\text { filtration efficiency. } \\
\text { Vibration increases } \\
\text { shear rate resulted to } \\
\text { moderate degree of } \\
\text { membrane fouling to } \\
\text { promote high flux. }\end{array}$ & $\begin{array}{l}\text { Vibration has low } \\
\text { energy consumption } \\
\text { due to the } \\
\text { interaction occurs } \\
\text { only at the } \\
\text { membrane surface } \\
\text { and the liquid only. } \\
\text { The membrane } \\
\text { surface-liquid occurs } \\
\text { due to the high } \\
\text { shear rates produces } \\
\text { from the vibration } \\
\text { system. }\end{array}$ & $\begin{array}{l}\text { (Bilad et al., } \\
\text { 2013) }\end{array}$ \\
\hline $\begin{array}{l}\text { Axial vibration } \\
\text { membrane } \\
\text { system }\end{array}$ & $\begin{array}{l}\text { At vibration of } 10 \mathrm{~Hz} \text {, } \\
\text { there was almost no } \\
\text { microalgae depositing } \\
\text { on membrane that } \\
\text { allows } 12 \text {-h sustained } \\
\text { filtration with only } \\
\text { slight flux decrease. } \\
\text { Flux of } 40\left(\mathrm{~L} / \mathrm{m}^{2} \mathrm{~h}^{2}\right) \\
\text { increment from } 0 \mathrm{~Hz} \\
\text { of } 15 \mathrm{~L} / \mathrm{m}^{2} \mathrm{~h}^{2} \text {. }\end{array}$ & $\begin{array}{l}\text { Axial motion in the } \\
\text { system makes the } \\
\text { foulant hard to stick } \\
\text { on the membrane } \\
\text { surface. }\end{array}$ & $\begin{array}{l}\text { (Zhao, Chu, } \\
\text { Tan, Zhang, et } \\
\text { al., 2016) }\end{array}$ \\
\hline $\begin{array}{l}\text { Disc-typed } \\
\text { Physical } \\
\text { cleaning to } \\
\text { allow } \\
\text { backwashing }\end{array}$ & $\begin{array}{l}\text { Backwashing for cell } \\
\text { at concentration } 6 \mathrm{~g} / \mathrm{L} \\
\text { have significant flux } \\
\text { at } 0.4 \mathrm{~J} / \mathrm{J}_{\mathrm{o}} \text { compared } \\
\text { to relaxation at } 0.3 \\
\mathrm{~J} / \mathrm{J}_{\mathrm{o}}\end{array}$ & $\begin{array}{l}\text { The fouling is } \\
\text { removed with the } \\
\text { inertia cause by the } \\
\text { axial vibration } \\
\text { system. }\end{array}$ & $\begin{array}{l}\text { (Kanchanatip et } \\
\text { al., 2016) }\end{array}$ \\
\hline $\begin{array}{l}\text { Addition of } \\
\text { turbulence } \\
\text { promoters in } \\
\text { the flow } \\
\text { channel of the } \\
\text { tubular flow }\end{array}$ & $\begin{array}{l}\text { The highest flux } \\
\text { improvement of } 140 \% \\
\text { can be reached by } \\
\text { applying a Kenics } \\
\text { mixer }\end{array}$ & $\begin{array}{l}\text { 3D printed } \\
\text { promoters promote } \\
\text { turbulence in the } \\
\text { flow, increase the } \\
\text { shear rates on the } \\
\text { membrane from the } \\
\text { feed flow in the } \\
\text { medium. }\end{array}$ & $\begin{array}{l}\text { (Armbruster et } \\
\text { al., 2018) }\end{array}$ \\
\hline $\begin{array}{l}\text { Rotation } \\
\text { increase shear }\end{array}$ & $\begin{array}{l}\text { The rotating disk } \\
\text { module offered low }\end{array}$ & $\begin{array}{l}\text { Rotation offer } \\
\text { turbulence in the }\end{array}$ & $\begin{array}{l}\text { (Frappart et al., } \\
\text { 2011) }\end{array}$ \\
\hline
\end{tabular}




\begin{tabular}{|c|c|c|c|}
\hline $\begin{array}{c}\text { Dynamic } \\
\text { Membrane } \\
\text { system }\end{array}$ & Performance & Remarks & Reference \\
\hline $\begin{array}{l}\text { rate compare } \\
\text { to tangential } \\
\text { flow }\end{array}$ & $\begin{array}{l}\text { fouling due to less } \\
\text { EPS. }\end{array}$ & $\begin{array}{l}\text { medium thus } \\
\text { increase shear rates. }\end{array}$ & \\
\hline $\begin{array}{l}\text { Aeration for } \\
\text { fouling control }\end{array}$ & $\begin{array}{l}\text { Vibrating membrane } \\
\text { system could } \\
\text { maintain permeance } \\
\text { over multiple-stage } \\
\text { fed-batch filtrations }\end{array}$ & $\begin{array}{l}\text { Air bubbles are } \\
\text { applied as the } \\
\text { cleaning method to } \\
\text { the membrane. They } \\
\text { scour off the } \\
\text { reversible fouling on } \\
\text { the membrane. }\end{array}$ & $\begin{array}{l}\text { (Alipourzadeh } \\
\text { et al., 2016; } \\
\text { Bilad, Arafat, et } \\
\text { al., 2014; Chen } \\
\text { et al., 2012) }\end{array}$ \\
\hline & & $\begin{array}{l}\text { High aeration rate } \\
\text { provides more } \\
\text { bubbles and gives } \\
\text { better flux. }\end{array}$ & \\
\hline
\end{tabular}

\section{Improved module design}

Table 5 summarizes report on improved module design for membrane fouling control. Aeration is an established method for membrane fouling control in submerged filtration system. Many of the report focus on the improvement of air bubble efficiency or propose alternative to replace the aeration in microalgae harvesting using membrane filtration (Bilad, Marbelia, et al., 2014).

To improve the performance of membrane, Hwang et al., (2015b) had propose to add aeration into the system in a horizontal membrane panel. The idea of adding the aeration is to create air bubbles into the system. The buoyance force lifts the bubbles to move and push away the foulant on the surface of the membrane. Studies made by Hwang et al. (2015b) show that permeability of the membrane increases with the presence of the bubble that make good contact on the surface of the membrane to scour off foulant. Buoyancy force helps the bubbles to drag itself upwards and take away the foulant from the membrane surface.

Eliseus et al. (2017) proposed to tilt the panel of the membrane and allow the aeration bubbles to drag the foulant on the membrane surface. Under such system, the drag force acting on membrane surface is function of buoyancy force and tilting angle. The increment of drag exerts the more force to push away the foulant.

Table 5. Improved module design to control fouling

\begin{tabular}{llll}
\hline $\begin{array}{c}\text { Improved Module } \\
\text { design }\end{array}$ & \multicolumn{1}{c}{ Performance } & Remarks & Reference \\
\hline $\begin{array}{l}\text { Incorporating } \\
\text { aeration into the } \\
\text { filtration system }\end{array}$ & $\begin{array}{l}\text { Biomass concentration } \\
\text { in aerated better than } \\
\text { vibrated system. } \\
\text { Permeance in vibrated } \\
\text { system double from } \\
\text { the aerated system. }\end{array}$ & $\begin{array}{l}\text { Reversible foulant } \\
\text { can be remove by } \\
\text { vibration system }\end{array}$ & $\begin{array}{l}\text { Bilad et al., } \\
(2014 \mathrm{~b})\end{array}$ \\
& & & \\
\hline
\end{tabular}




\begin{tabular}{|c|c|c|c|}
\hline $\begin{array}{c}\text { Improved Module } \\
\text { design }\end{array}$ & Performance & Remarks & Reference \\
\hline $\begin{array}{l}\text { Horizontal } \\
\text { membrane panel }\end{array}$ & $\begin{array}{l}\text { Membranes P-PVDF } \\
\text { and C-PVDF show } \\
\text { improvement of } 133 \% \\
\text { and } 45 \% \text { with the } \\
\text { presence of bubble } \\
\text { plate. }\end{array}$ & $\begin{array}{l}\text { Buoyancy force } \\
\text { helps the bubbles } \\
\text { to drag itself } \\
\text { upwards and take } \\
\text { away the foulant } \\
\text { from the } \\
\text { membrane surface. }\end{array}$ & $\begin{array}{l}\text { Hwang et } \\
\text { al. (2015b) }\end{array}$ \\
\hline $\begin{array}{l}\text { Tilted the panel of } \\
\text { membrane }\end{array}$ & $\begin{array}{l}\text { Tilting the panel at } \\
\text { angle of } 20^{\circ} \text { offers the } \\
\text { highest permeance } \\
\left(225 \mathrm{~L} / \mathrm{m}^{2} \mathrm{~h} \text { bar }\right) \text {. }\end{array}$ & $\begin{array}{l}\text { The drag force on } \\
\text { the bubbles } \\
\text { increase with } \\
\text { increase of angle of } \\
\text { tilted panel } \\
\text { because of higher } \\
\text { bubble contacts to } \\
\text { the membrane } \\
\text { surface. }\end{array}$ & $\begin{array}{l}\text { Eliseus et } \\
\text { al. (2017) }\end{array}$ \\
\hline
\end{tabular}

\section{Membrane spacer development}

Table 6 summarizes the type of membrane spacers used to improve membrane performance. Most of the reports focus on development of spacer for spiral-wound module. Only limited literature is available on the plate-and-frame module.

Feed spacers have long been used to reduce fouling by increase the shear forces (Abid et al., 2017) and local mixing along the feed channel and thus improves the mass transfer in the membrane modules (Fritzmann et al., 2013). Coated spacer performs better than uncoated spacer in term of flux and antifouling effect. Type of coating varies based on the type of cell and application of the module (i.e., nano silver coating and propylene coating). Gold coated spacer can reduce biofouling in the membrane modules (Abid et al., 2017). However, in other study, silver coated membrane perform better in application of seawater (Yang et al., 2009). Coating of copper into spacer is found beneficial to slow down the accumulation of biofouling. It is better than polydopamine coated spacer which only increase hydrophilicity but fails to inhibit biofouling (Araújo et al., 2012). However, the coated materials degrade over time as the coating layer will reduce with time.

Geometry of the spacers (such as size and thickness) also affects to the membrane module performance (Abid et al., 2017). Hairy structures was introduced into a spacer mesh and improve performance thanks to their vibration that improve the mass transfer and permeability (Li et al., 2016). The movement of the hairy fibers were observed. Vibrations of the hairy structures induce fluid instability, increase the mass transfer rate and mitigate membrane fouling by reducing deposits of the fouling particles on the membrane surface ( $\mathrm{Li}$ et al., 2016). The movement of the hairy fibers were observed and compared between uniform and asymmetric fiber. They capture that asymmetric fiber allows better flux as it is more flexible compare to uniform fiber as hairy structures can be place very close to the membrane. Vibration from the fibers will help to mitigate fouling and reduce the reversible foulant on the membrane. 
Orientation of the spacers play roles in determine the degree of turbulence of the water (Jianxin Liu et al., 2015). A saw- tooth spacers (STS) improve the shear force 6.86 higher than a zigzag spacer (ZS). STS can generate higher turbulent kinetic energy and increase membrane shear rate and reduce fouling (Jianxin Liu et al., 2015). They also mentioned increase in tooth height caused formation recirculation flow and enhanced the filtration performance. The recirculation flow increased shear rates from the flow and helped to scour off the foulant on the membrane surface.

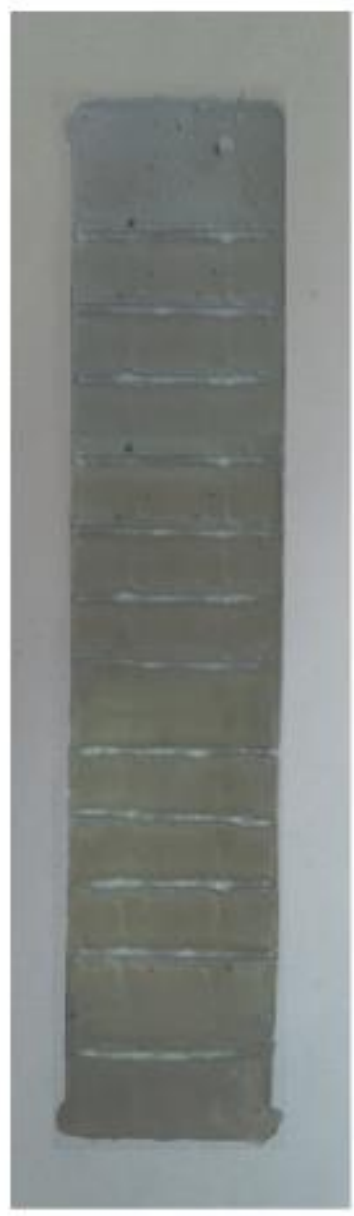

(a)

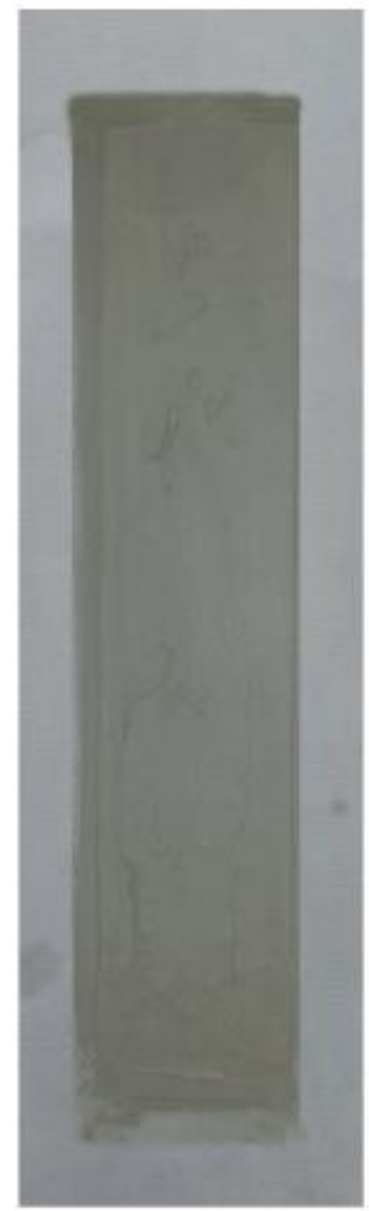

(b)

Figure 2. Picture of a) Zigzag typed spacer and b) Saw tooth spacer used to enhanced local mixing for membrane fouling control (Jianxin Liu et al., 2015)

Fully woven spacer configuration offers enhanced performance in terms of permeability and polarization of the concentration, the angle of the mesh decrease with the permeance (Gu et al., 2017). Fritzmann et al. (2014) stated that an appropriate geometry of spacers can improve the performance of membrane. The angle of the mesh affected the pressure drop (Gu et al., 2017) and angle of $90^{\circ}$ showed lowest pressure drop. High attack angle contributed swirling effect of the flow into the module, which helped to mitigate the adhesive solid foulant on the membrane surface.

A static mixing spacer has also been proven to improve the mass transfer coefficient of the fluid (Jiuqing Liu et al., 2013). These static spacers acted as the mixers on the fluid, which helps the fluid flow and contact with the membrane. Static mixing 
spacers provided higher mass transfer coefficients than the conventional spacer which provided better filtration performance at low flowrate (less turbulence) (Jiuqing Liu et al., 2013). Application of static mixers showed better permeance by $20 \%$ increment.

Researchers have taken the membrane development to another level by introducing 3D printing technology (Lee et al., 2016). A comparison study proved the 3D spacer and conventional feed spacer had similar characteristics such as: 1) hydrodynamic behavior, 2) biomass accumulation, and 3) pressure drop and development time, indicating 3D spacer is a promising alternative (Siddiqui et al., 2016). The feed spacer were used by the spiral wound membrane which required the stiffness of the spacers (Tan et al., 2016) . The mechanical strength of spacers made by polypropylene increased (Siddiqui et al., 2016). The 3D technology also aimed to reduce the biofilm form on the membrane (Siddiqui et al., 2016). Hence, 3D technology can help to customize the spacers based on the needs of the modules and type of cells.
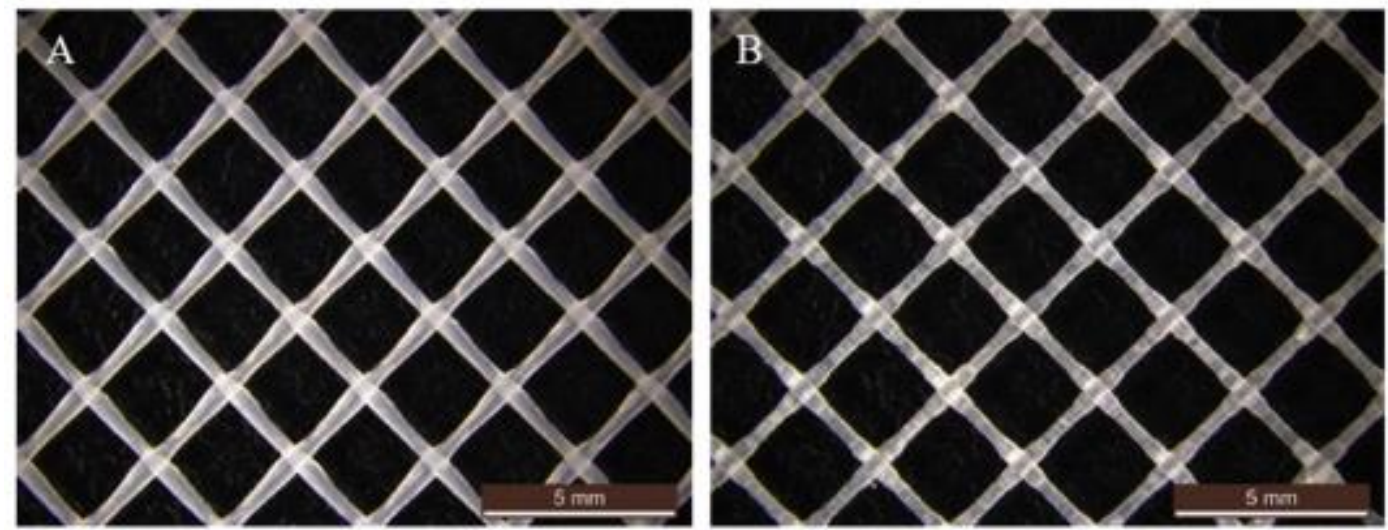

Figure 3. Standard feed spacer and newly developed 3D feed spacer (Siddiqui et al., 2016) for enhancing local mixing and membrane fouling control.

Table 6. Type of membrane spacer

\begin{tabular}{|c|c|c|c|}
\hline $\begin{array}{c}\text { Type of } \\
\text { membrane spacer }\end{array}$ & Performance & Remarks & Author \\
\hline $\begin{array}{lr}\text { Gold } & \text { coated } \\
\text { spacer } & \text { with } \\
\text { polydopamine-g- } \\
\text { PEG }\end{array}$ & $\begin{array}{l}\text { Gold coated and silver- } \\
\text { coated spacer have the } \\
\text { best control on } \\
\text { biofouling effect. } \\
\text { The antifouling effects } \\
\text { degrades over time.. } \\
\text { Polydopamine } \\
\text { increased the } \\
\text { hydrophilicity however } \\
\text { failed to inhibit } \\
\text { biofouling } \\
\text { Copper slowing down } \\
\text { the accumulation of the } \\
\text { biofouling, but not } \\
\text { satisfy long term } \\
\text { filtration }\end{array}$ & $\begin{array}{l}\text { Coated spacer } \\
\text { performs better than } \\
\text { uncoated spacer. } \\
\text { Type of coating vary } \\
\text { based on the type of } \\
\text { cell. }\end{array}$ & $\begin{array}{l}\text { (Abid et al., } \\
\text { 2017; } \\
\text { Araújo et } \\
\text { al., 2012; } \\
\text { Yang et al., } \\
\text { 2009) }\end{array}$ \\
\hline
\end{tabular}




\begin{tabular}{|c|c|c|c|}
\hline $\begin{array}{c}\text { Type of } \\
\text { membrane spacer }\end{array}$ & Performance & Remarks & Author \\
\hline $\begin{array}{l}\text { Hairy structures } \\
\text { into the spacer } \\
\text { mesh }\end{array}$ & $\begin{array}{l}\text { The hairy structure is } \\
\text { incorporated into net- } \\
\text { spacer. } \\
\text { Vibrations of the hairy } \\
\text { structures induce fluid } \\
\text { instability, increase the } \\
\text { mass transfer rate and } \\
\text { mitigate membrane } \\
\text { fouling by } \\
\text { reducing deposits of the } \\
\text { fouling particles on the } \\
\text { membrane surface. }\end{array}$ & $\begin{array}{l}\text { Vibration from the } \\
\text { fibers will help to } \\
\text { mitigate fouling and } \\
\text { reduce the reversible } \\
\text { foulant on the } \\
\text { membrane. }\end{array}$ & $\begin{array}{l}\text { (Li et al., } \\
2016)\end{array}$ \\
\hline $\begin{array}{l}\text { Saw- tooth } \\
\text { spacers (STS) }\end{array}$ & $\begin{array}{l}\text { STS can generate higher } \\
\text { turbulent kinetic energy } \\
\text { and increase membrane } \\
\text { shear rate and reduce } \\
\text { fouling. } \\
\text { Increase in tooth height, } \\
\text { cause formation } \\
\text { recirculation flow, } \\
\text { better filtration } \\
\text { performance }\end{array}$ & $\begin{array}{l}\text { The recirculation flow } \\
\text { increases shear rates } \\
\text { from the flow and } \\
\text { helps to scour off the } \\
\text { foulant on the } \\
\text { membrane surface }\end{array}$ & $\begin{array}{l}\text { (Jianxin Liu } \\
\text { et al., 2015) }\end{array}$ \\
\hline $\begin{array}{l}\text { Fully woven } \\
\text { Increase the angle } \\
\text { of the mesh }\end{array}$ & $\begin{array}{l}\text { Using woven type } \\
\text { spacer varies the mesh } \\
\text { angle. } \\
\text { Reducing angle mesh } \\
\text { reduced the water flux. }\end{array}$ & $\begin{array}{l}\text { High attack angle } \\
\text { contribute swirling } \\
\text { effect into the module } \\
\text { helps to mitigate the } \\
\text { adhesive solid on the } \\
\text { membrane. }\end{array}$ & $\begin{array}{c}\text { (Abid et al., } \\
\text { 2017; Gu et } \\
\text { al., 2017) }\end{array}$ \\
\hline $\begin{array}{l}\text { Static } \\
\text { spacer }\end{array}$ & $\begin{array}{l}\text { Spacer with static } \\
\text { mixing enhanced mass } \\
\text { transfer coefficients. } \\
\text { Have better filtration } \\
\text { performance at low } \\
\text { flowrate } \\
\text { turbulence). }\end{array}$ & $\begin{array}{l}\text { These static spacers } \\
\text { act as the mixers on } \\
\text { the fluid which helps } \\
\text { the fluid flow and } \\
\text { contact with the } \\
\text { membrane. }\end{array}$ & $\begin{array}{l}\text { Liu et al., } \\
\text { 2013; } \\
\text { Siddiqui et } \\
\text { al., 2016; } \\
\text { Tan et al. } \\
\text { (2016) }\end{array}$ \\
\hline 3D spacer & $\begin{array}{l}\text { The feed spacer used by } \\
\text { the spiral wound } \\
\text { membrane which } \\
\text { require the stiffness of } \\
\text { the spacers. } \\
\text { Mechanical strength of } \\
\text { spacers made by } \\
\text { polypropylene } \\
\text { increased. }\end{array}$ & $\begin{array}{l}\text { 3D technology helps } \\
\text { to customize the } \\
\text { spacers based on the } \\
\text { needs of the modules } \\
\text { and type of cells }\end{array}$ & $\begin{array}{l}\text { Hwang et } \\
\text { al., 2015a }\end{array}$ \\
\hline
\end{tabular}


Table 7 summarizes the permeance achieved by the various module system. The axial vibration membrane system gives higher permeance $640 \mathrm{~L}^{-2} \mathrm{~m}^{-1} \cdot \mathrm{bar}$ (Zhao, $\mathrm{Chu}$, Su, et al., 2016), while other study using finned spacer offers better permeance of $870 \pm 11 \mathrm{~L} \mathrm{~m}^{-2} \cdot \mathrm{h}^{-1}$ bar (Razak et al., 2020). Other aerated systems such as the one reported earlier (Alipourzadeh et al., 2016; Bilad et al., 2014b; Chen et al., 2012; Eliseus et al., 2017) offer low permeance $320 \pm 00 \mathrm{~L} \mathrm{~m}^{-2} \cdot \mathrm{h}^{-1}$ bar proves that aeration alone not sufficient for fouling control. Non-uniform movement of the bubbles makes aeration could not afford to clean foulant on membrane surface. Finned spacer has improved fouling control for microalgae harvesting better than conventional technique available. The finned spacer system can gives high permeance as comparing with other microalgae filtration (Razak et al., 2020). Not only gives higher permeance, it can offer other advantages such as lower foot print, lower mechanical loads, simple operation and make it easy to scale up in the industry. This system also could operate simultaneously clean both sides of the panel.

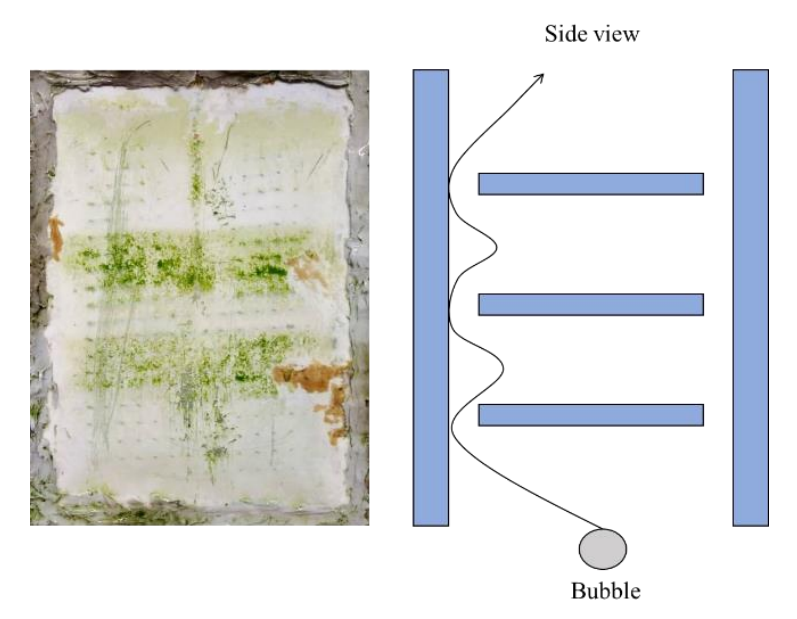

Figure 4. (left) A picture of fouled membrane showen by gneen color of microalgae biomass attached to the membrane surface on the areas with less exposure of air bubbles and (right) illustration of relative placement of the fins in a spacer system (Razak et al., 2020)

Table 7. Performance comparison of fouling control system under different module concepts.

\begin{tabular}{|c|c|c|c|c|c|}
\hline $\begin{array}{l}\text { Fouling } \\
\text { control system }\end{array}$ & $\begin{array}{l}\text { Feed concentration } \\
\text { and microalgae } \\
\text { species }\end{array}$ & $\begin{array}{l}\text { Membrane } \\
\text { material }\end{array}$ & $\begin{array}{l}\text { Flux } \\
\left(\mathrm{L} /\left(\mathrm{m}^{2} \mathrm{~h}\right)\right)\end{array}$ & $\begin{array}{l}\text { Permeability } \\
\left(\mathrm{L} /\left(\mathrm{m}^{2} \mathrm{~h} \text { bar }\right)\right)\end{array}$ & Reference \\
\hline Finned spacer & $1.15 \mathrm{~g} \mathrm{~L}^{-1}$ of Chlorella & PVDF & 87 & 870 & $\begin{array}{l}\text { (Razak et } \\
\text { al., 2020) }\end{array}$ \\
\hline $\begin{array}{l}\text { Tilted panel } \\
\text { with optimum } \\
\text { membrane }\end{array}$ & $0.6 \mathrm{~g} \mathrm{~L}^{-1}$ of Euglena $\mathrm{Sp}$. & PVDF & 72 & 724 & $\begin{array}{l}\text { (Lau et al., } \\
\text { 2020) }\end{array}$ \\
\hline Tilted panel & $1 \mathrm{~g} \mathrm{~L}^{-1}$ of Euglena $s p$. & $\begin{array}{l}15 \% \mathrm{wt} \\
\text { PVDF }\end{array}$ & 22.5 & 225 & $\begin{array}{l}\text { (Eliseus et } \\
\text { al., 2017) }\end{array}$ \\
\hline
\end{tabular}




\begin{tabular}{|c|c|c|c|c|c|}
\hline $\begin{array}{l}\text { Fouling } \\
\text { control system }\end{array}$ & $\begin{array}{l}\text { Feed concentration } \\
\text { and microalgae } \\
\text { species }\end{array}$ & $\begin{array}{l}\text { Membrane } \\
\text { material }\end{array}$ & $\begin{array}{l}\text { Flux } \\
\left(\mathrm{L} /\left(\mathrm{m}^{2} h\right)\right)\end{array}$ & $\begin{array}{l}\text { Permeability } \\
\left(\mathrm{L} /\left(\mathrm{m}^{2} \mathrm{~h} \text { bar }\right)\right)\end{array}$ & Reference \\
\hline $\begin{array}{l}\text { Membrane } \\
\text { vibrations }\end{array}$ & $\begin{array}{l}0.25 \mathrm{~g} \mathrm{~L}^{-1} \text { of } \\
\text { Phaeodactylum } \\
\text { tricornutum } \\
0.21 \mathrm{~g} \mathrm{~L}^{-1} \text { of Chlorella } \\
\text { vulgaris }\end{array}$ & $\begin{array}{l}9 \% \text { and } \\
12 \% \text { wt } \\
\text { PVDF }\end{array}$ & $\begin{array}{l} \pm 21.25- \\
42.5 \\
\pm 25.5-42.5\end{array}$ & $\begin{array}{l}212.5-425^{*} \\
255-425^{*}\end{array}$ & $\begin{array}{l}\text { (Bilad et } \\
\text { al., 2013) }\end{array}$ \\
\hline Axial vibration & $\begin{array}{l}0.55 \mathrm{~g} \mathrm{~L}^{-1} \text { of Chlorella } \\
\text { pyrenoidosa }\end{array}$ & PVDF & $22-64^{* *}$ & $220-640$ & $\begin{array}{l}\text { (Zhao, } \\
\text { Chu, Su, et } \\
\text { al., 2016) }\end{array}$ \\
\hline $\begin{array}{l}\text { Disc type } \\
\text { panel }\end{array}$ & $\begin{array}{l}10 \mathrm{~g} \mathrm{~L}^{-1} \text { of Arthrospira } \\
\text { maxima }\end{array}$ & PVDF & $57-143$ & $95-238.3$ & $\begin{array}{l}\text { (Kanchana } \\
\text { tip et al., } \\
2016 \text { ) }\end{array}$ \\
\hline $\begin{array}{l}\text { Aeration in } \\
\text { vertical panel }\end{array}$ & $\begin{array}{l}0.65 \mathrm{~g} \mathrm{~L}^{-1} \text { of Chlorella } \\
\text { vulgaris }\end{array}$ & $\begin{array}{l}\text { MCE } \\
\text { (micro } \\
\text { cellulose } \\
\text { ester) }\end{array}$ & $11.6-20.5$ & $23.2-41$ & $\begin{array}{l}\text { (Alipourza } \\
\text { deh et al., } \\
2016 \text { ) }\end{array}$ \\
\hline $\begin{array}{l}\text { Backwashing } \\
\text { and ventilation }\end{array}$ & Scenedesmus sp. & PVDF & 130 & 260 & $\begin{array}{l}\text { (Chen et } \\
\text { al., 2012) }\end{array}$ \\
\hline $\begin{array}{l}\text { Vibration and } \\
\text { aeration }\end{array}$ & $\begin{array}{l}0.08 \mathrm{~g} \mathrm{~L}^{-1} \text { of Chlorella } \\
\text { vulgaris }\end{array}$ & PVDF & 32.5 & 325 & $\begin{array}{l}\text { (Bilad, } \\
\text { Marbelia, } \\
\text { et al., 2014) }\end{array}$ \\
\hline $\begin{array}{l}\text { Axial vibration } \\
\text { membrane } \\
\text { system }\end{array}$ & $\begin{array}{l}0.3 \mathrm{~g} \mathrm{~L}^{-1} \text { of Chlorella } \\
\text { pyrenoidosa }\end{array}$ & PVDF & 60 & 85.71 & $\begin{array}{l}\text { (Zhao, } \\
\text { Chu, Tan, } \\
\text { Yang, et } \\
\text { al., 2016) }\end{array}$ \\
\hline $\begin{array}{l}\text { Axial vibration } \\
\text { and aeration }\end{array}$ & $\begin{array}{l}0.3 \mathrm{~g} \mathrm{~L}^{-1} \text { of Chlorella } \\
\text { pyrenoidosa }\end{array}$ & PVDF & 238.4 & 340.57 & $\begin{array}{l}\text { (Zhao, } \\
\text { Chu, Tan, } \\
\text { Zhang, et } \\
\text { al., 2016) }\end{array}$ \\
\hline $\begin{array}{l}\text { Submerged } \\
\text { microfiltration }\end{array}$ & $\begin{array}{l}0.41 \pm 0.05 \mathrm{~g} \mathrm{~L}^{-1} \text { of } \\
\text { Chlorella vulgaris } \\
0.23 \pm 0.06 \mathrm{~g} \mathrm{~L}^{-1} \text { of } \\
\text { Phaeodactylum } \\
\text { tricornutum }\end{array}$ & PVDF & $32-50$ & $320-500$ & $\begin{array}{l}\text { (Bilad et } \\
\text { al., 2012) }\end{array}$ \\
\hline
\end{tabular}

All data from references have been taken directly unless otherwise specified as below. The permeance was calculated based on given flux and TMP. When no TMP data is available, the permeance was calculated from the reported flux $\left(^{*}\right)$ or critical flux $\left(^{* *}\right)$ by assuming the TMP 0.1 bar.

\section{CONCLUDING REMARKS}

In general, membrane technology is a promising method for harvesting microalgae especially when targeting the high-quality product that demand no chemical contamination which is vital for food and feed industry. Since membrane fouling often limits the performance of this technology, researchers have been extensively putting effort on the viable and practical methods to cater the fouling 
issue. Thus, several methods have been introduced including physical cleaning, dynamic filtration system and improved air bubbling system.

Air bubbles is promising alternative to control fouling, but the effectiveness is low in the conventional vertical system. Improvement are made in module design of the membrane filtration system as summarize in Table 3. Poor contact between membrane and the air bubbles become another challenge to the system. Switching the panel contribute to complexity of operation and energy consumption in the system. Spacer has been used to improve filterability of the membrane in terms of mass transfer in the fluid as shown in Table 4. Substantial development on module spacer have been reported recently to improve filtration. The spacer can be incorporated into a module system and can be designed to encourage air bubbles flowrate atop the membrane surface, hence improve their cleaning efficacy.

The success of lab-scale experiments must be translated into larger scale to show if the innovation provided is really applicable. The research on microalgae harvesting must also be accompanied by techno-economic and lifecycle analysis to fairly judge the potential of microalgae biomass for biofuel application. Lastly, the vast knowledge and developments on microalgae filtration can be implemented for other purposes, such as microalgae for feed and food supplements. Those bioproducts have reach commercialization stage, unlike for biofuel. Implementation of membrane-based microalgae harvesting will only enhance its competitiveness, either in term of enhancement of product quality (because the absence of chemicals) or through improvement in production efficiency due to low-cost and energy using membranebased processes.

\section{REFERENCES}

Abid, H. S., Johnson, D. J., Hashaikeh, R., \& Hilal, N. (2017). A review of efforts to reduce membrane fouling by control of feed spacer characteristics. Desalination, 420, 384-402. https:/ / doi.org/10.1016/j.desal.2017.07.019

Alipourzadeh, A., Mehrnia, M. R., Sani, A. H., \& Babaei, A. (2016). Application of response surface methodology for investigation of membrane fouling behaviours in microalgal membrane bioreactor: The effect of aeration rate and biomass concentration. RSC Advances, 6(112), 111182-111189. https://doi.org/10.1039/C6RA23188H

Amer, L., Adhikari, B., \& Pellegrino, J. (2011). Technoeconomic analysis of five microalgae-to-biofuels processes of varying complexity. Bioresource Technology, 102(20), 9350-9359. https://doi.org/10.1016/j.biortech.2011.08.010

Araújo, P. A., Miller, D. J., Correia, P. B., van Loosdrecht, M. C. M., Kruithof, J. C., Freeman, B. D., Paul, D. R., \& Vrouwenvelder, J. S. (2012). Impact of feed spacer and membrane modification by hydrophilic, bactericidal and biocidal coating on biofouling control. Desalination, 295, 1-10. https://doi.org/10.1016/j.desal.2012.02.026

Armbruster, S., Cheong, O., Lölsberg, J., Popovic, S., Yüce, S., \& Wessling, M. (2018). Fouling mitigation in tubular membranes by 3D-printed turbulence promoters. Journal of Membrane Science, 554, 156-163. https:/ / doi.org/10.1016/j.memsci.2018.02.015 
Barros, A. I., Gonçalves, A. L., Simões, M., \& Pires, J. C. M. (2015). Harvesting techniques applied to microalgae: A review. Renewable and Sustainable Energy Reviews, 41, 1489-1500. https:// doi.org/10.1016/j.rser.2014.09.037

Beilen, J. B. van. (2010). Why microalgal biofuels won't save the internal combustion machine. Biofuels, Bioproducts and Biorefining, 4(1), 41-52. https://doi.org/10.1002/bbb.193

Bharathiraja, B., Chakravarthy, M., Ranjith Kumar, R., Yogendran, D., Yuvaraj, D., Jayamuthunagai, J., Praveen Kumar, R., \& Palani, S. (2015). Aquatic biomass (algae) as a future feed stock for bio-refineries: A review on cultivation, processing and products. Renewable and Sustainable Energy Reviews, 47, 634-653. https:/ / doi.org/10.1016/j.rser.2015.03.047

Bilad, M. R., Arafat, H. A., \& Vankelecom, I. F. J. (2014). Membrane technology in microalgae cultivation and harvesting: A review. Biotechnology Advances, 32(7), 1283-1300. https://doi.org/10.1016/j.biotechadv.2014.07.008

Bilad, M. R., Discart, V., Vandamme, D., Foubert, I., Muylaert, K., \& Vankelecom, I. F. J. (2013). Harvesting microalgal biomass using a magnetically induced membrane vibration (MMV) system: Filtration performance and energy consumption. Bioresource Technology, 138, 329-338. https://doi.org/10.1016/j.biortech.2013.03.175

Bilad, M. R., Marbelia, L., Naik, P., Laine, C., \& Vankelecom, I. F. J. (2014). Direct comparison of aerated and vibrated filtration systems for harvesting of Chlorella vulgaris. Algal Research, 6, 32-38. https://doi.org/10.1016/j.algal.2014.09.001

Bilad, M. R., Vandamme, D., Foubert, I., Muylaert, K., \& Vankelecom, I. F. J. (2012). Harvesting microalgal biomass using submerged microfiltration membranes. Bioresource Technology, 111, 343-352. https://doi.org/10.1016/j.biortech.2012.02.009

Castel, C., \& Favre, E. (2018). Membrane separations and energy efficiency. Journal of Membrane Science, 548, 345-357. https://doi.org/10.1016/j.memsci.2017.11.035

Chen, X., Huang, C., \& Liu, T. (2012). Harvesting of microalgae Scenedesmus sp. Using polyvinylidene fluoride microfiltration membrane. Desalination and Water Treatment, 45(1-3), 177-181. https:/ / doi.org/10.1080/19443994.2012.692034

Chin, H. J., Shen, T. F., Su, H. P., \& Ding, S. T. (2006). Schizochytrium limacinum SR21 as a source of docosahexaenoic acid: Optimal growth and use as a dietary supplement for laying hens. Australian Journal of Agricultural Research, 57(1), 13. https://doi.org/10.1071/AR05099

Chiu, S.-Y., Kao, C.-Y., Tsai, M.-T., Ong, S.-C., Chen, C.-H., \& Lin, C.-S. (2009). Lipid accumulation and $\mathrm{CO} 2$ utilization of Nannochloropsis oculata in response to CO2 aeration. Bioresource Technology, 100(2), 833-838. https://doi.org/10.1016/j.biortech.2008.06.061

Demirbas, A., \& Demirbas, M. F. (2010). Algae Energy: Algae as a New Source of Biodiesel. Springer-Verlag. https://www.springer.com/gp/book/9781849960496

Discart, V., Bilad, M. R., Moorkens, R., Arafat, H., \& Vankelecom, I. F. J. (2015). Decreasing membrane fouling during Chlorella vulgaris broth filtration via membrane development and coagulant assisted filtration. Algal Research, 9, 5564. https://doi.org/10.1016/j.algal.2015.02.029 
Eliseus, A., Bilad, M. R., Nordin, N. A. H. M., Putra, Z. A., \& Wirzal, M. D. H. (2017). Tilted membrane panel: A new module concept to maximize the impact of air bubbles for membrane fouling control in microalgae harvesting. Bioresource Technology, 241, 661-668. https:// doi.org/10.1016/j.biortech.2017.05.175

Frappart, M., Massé, A., Jaffrin, M. Y., Pruvost, J., \& Jaouen, P. (2011). Influence of hydrodynamics in tangential and dynamic ultrafiltration systems for microalgae separation. Desalination, 265(1), 279-283. https://doi.org/10.1016/j.desal.2010.07.061

Fritzmann, C., Hausmann, M., Wiese, M., Wessling, M., \& Melin, T. (2013). Microstructured spacers for submerged membrane filtration systems. Journal of Membrane Science, 446, 189-200. https:/ / doi.org/10.1016/j.memsci.2013.06.033

Fritzmann, C., Wiese, M., Melin, T., \& Wessling, M. (2014). Helically microstructured spacers improve mass transfer and fractionation selectivity in ultrafiltration. Journal of Membrane Science, 463, 41-48. https://doi.org/10.1016/j.memsci.2014.03.059

Gu, B., Adjiman, C. S., \& Xu, X. Y. (2017). The effect of feed spacer geometry on membrane performance and concentration polarisation based on 3D CFD simulations. Journal of Membrane Science, 527, 78-91. https://doi.org/10.1016/j.memsci.2016.12.058

Hausman, R., Gullinkala, T., \& Escobar, I. (2009). Development of Low-Biofouling Polypropylene Feedspacers for Reverse Osmosis. Journal of Applied Polymer Science, 114, 3068-3073. https://doi.org/10.1002/app.30755

Hwang, T., Kotte, M. R., Han, J.-I., Oh, Y.-K., \& Diallo, M. S. (2015). Microalgae recovery by ultrafiltration using novel fouling-resistant PVDF membranes with in situ PEGylated polyethyleneimine particles. Water Research, 73, 181-192. https://doi.org/10.1016/j.watres.2014.12.002

Hwang, T., Oh, Y.-K., Kim, B., \& Han, J.-I. (2015). Dramatic improvement of membrane performance for microalgae harvesting with a simple bubble-generator plate. Bioresource Technology, 186,

343-347. https://doi.org/10.1016/j.biortech.2015.03.111

Illman, A. M., Scragg, A. H., \& Shales, S. W. (2000). Increase in Chlorella strains calorific values when grown in low nitrogen medium. Enzyme and Microbial Technology, 27(8), 631-635. https:/ / doi.org/10.1016/S0141-0229(00)00266-0

Kalacheva, G. S., Zhila, N. O., \& Volova, T. G. (2002). Lipid and hydrocarbon compositions of a collection strain and a wild sample of the green microalga Botryococcus. Aquatic Ecology, 36(2), 317-331. https://doi.org/10.1023/A:1015615618420

Kanchanatip, E., Su, B.-R., Tulaphol, S., Den, W., Grisdanurak, N., \& Kuo, C.-C. (2016). Fouling characterization and control for harvesting microalgae Arthrospira (Spirulina) maxima using a submerged, disc-type ultrafiltration membrane. Bioresource Technology, 209, 23-30. https://doi.org/10.1016/j.biortech.2016.02.081

Lau, A. K. S., Bilad, M. R., Nordin, N. A. H. M., Faungnawakij, K., Narkkun, T., Wang, D. K., Mahlia, T. M. I., \& Jaafar, J. (2020). Effect of membrane properties on tilted panel performance of microalgae biomass filtration for biofuel feedstock. 
Renewable and Sustainable Energy Reviews, 120, 109666. https://doi.org/10.1016/j.rser.2019.109666

Lee, J.-Y., Tan, W. S., An, J., Chua, C. K., Tang, C. Y., Fane, A. G., \& Chong, T. H. (2016). The potential to enhance membrane module design with 3D printing technology. Journal of Membrane Science, 499, 480-490. https://doi.org/10.1016/j.memsci.2015.11.008

Li, W., Chen, K. K., Wang, Y.-N., Krantz, W. B., Fane, A. G., \& Tang, C. Y. (2016). A conceptual design of spacers with hairy structures for membrane processes. Journal of Membrane Science, 510, 314-325. https:/ / doi.org/10.1016/j.memsci.2016.03.021

Liang, Y. Y., Chapman, M. B., Fimbres Weihs, G. A., \& Wiley, D. E. (2014). CFD modelling of electro-osmotic permeate flux enhancement on the feed side of a membrane module. Journal of Membrane Science, 470, 378-388. https:/ / doi.org/10.1016/j.memsci.2014.07.039

Liu, Jianxin, Liu, Z., Xu, X., \& Liu, F. (2015). Saw-tooth spacer for membrane filtration: Hydrodynamic investigation by PIV and filtration experiment validation. Chemical Engineering and Processing: Process Intensification, 91, 23-34. https://doi.org/10.1016/j.cep.2015.03.013

Liu, Jiuqing, Iranshahi, A., Lou, Y., \& Lipscomb, G. (2013). Static mixing spacers for spiral wound modules. Journal of Membrane Science, 442, 140-148. https://doi.org/10.1016/j.memsci.2013.03.063

Maeda, Y., Yoshino, T., Matsunaga, T., Matsumoto, M., \& Tanaka, T. (2018). Marine microalgae for production of biofuels and chemicals. Current Opinion in Biotechnology, 50, 111-120. https://doi.org/10.1016/j.copbio.2017.11.018

Mandal, S., \& Mallick, N. (2009). Microalga Scenedesmus obliquus as a potential source for biodiesel production. Applied Microbiology and Biotechnology, 84(2), 281-291. https://doi.org/10.1007/s00253-009-1935-6

Marbelia, L., Bilad, M. R., Maes, S., Arafat, H. A., \& Vankelecom, I. F. J. (2018). Poly(vinylidene fluoride)-Based Membranes for Microalgae Filtration. Chemical Engineering \& Technology. https://doi.org/10.1002/ceat.201700622

Marbelia, L., Mulier, M., Vandamme, D., Muylaert, K., Szymczyk, A., \& Vankelecom, I. F. J. (2016). Polyacrylonitrile membranes for microalgae filtration: Influence of porosity, surface charge and microalgae species on membrane fouling. Algal Research, 19, 128-137. https:/ / doi.org/10.1016/j.algal.2016.08.004

Mata, T. M., Martins, A. A., \& Caetano, Nidia. S. (2010). Microalgae for biodiesel production and other applications: A review. Renewable and Sustainable Energy Reviews, 14(1), 217-232. https:/ / doi.org/10.1016/j.rser.2009.07.020

Milledge, J. J., \& Heaven, S. (2013). A review of the harvesting of micro-algae for biofuel production. Reviews in Environmental Science and Bio/Technology, 12(2), 165-178. https:/ / doi.org/10.1007/s11157-012-9301-z

Molina Grima, E., Belarbi, E.-H., Acién Fernández, F. G., Robles Medina, A., \& Chisti, Y. (2003). Recovery of microalgal biomass and metabolites: Process options and economics. Biotechnology Advances, 20(7), 491-515. https:/ / doi.org/10.1016/S0734-9750(02)00050-2

Natrah, F. M. I., Yusoff, F. M., Shariff, M., Abas, F., \& Mariana, N. S. (2007). Screening of Malaysian indigenous microalgae for antioxidant properties and nutritional 
value. Journal of Applied Phycology, 19(6), 711-718. https://doi.org/10.1007/s10811-007-9192-5

Qari, H., Rehan, M., \& Nizami, A.-S. (2017). Key Issues in Microalgae Biofuels: A Short Review. Energy Procedia, 142, 898-903. https://doi.org/10.1016/j.egypro.2017.12.144

Raheem, A., Prinsen, P., Vuppaladadiyam, A. K., Zhao, M., \& Luque, R. (2018). A review on sustainable microalgae based biofuel and bioenergy production: Recent developments. Journal of Cleaner Production, 181, 42-59. https:// doi.org/10.1016/j.jclepro.2018.01.125

Razak, N. N. A. N., Rahmawati, R., Bilad, M. R., Pratiwi, A. E., Elma, M., Nawi, N. I. M., Jaafar, J., \& Lam, M. K. (2020). Finned spacer for enhancing the impact of air bubbles for membrane fouling control in Chlorella vulgaris filtration. Bioresource Technology Reports, 11, 100429. https:/ / doi.org/10.1016/j.biteb.2020.100429

Rodolfi, L., Chini Zittelli, G., Bassi, N., Padovani, G., Biondi, N., Bonini, G., \& Tredici, M. R. (2009). Microalgae for oil: Strain selection, induction of lipid synthesis and outdoor mass cultivation in a low-cost photobioreactor. Biotechnology and Bioengineering, 102(1), 100-112. https://doi.org/10.1002/bit.22033

Scragg, A. H., Illman, A. M., Carden, A., \& Shales, S. W. (2002). Growth of microalgae with increased calorific values in a tubular bioreactor. Biomass and Bioenergy, 23(1), 67-73. https://doi.org/10.1016/S0961-9534(02)00028-4

Shen, Y., Yuan, W., Pei, Z., \& Mao, E. (2010). Heterotrophic Culture of Chlorella protothecoides in Various Nitrogen Sources for Lipid Production. Applied Biochemistry and Biotechnology, 160(6), 1674-1684. https:/ / doi.org/10.1007/s12010-009-8659-z

Siddiqui, A., Farhat, N., Bucs, S. S., Linares, R. V., Picioreanu, C., Kruithof, J. C., van Loosdrecht, M. C. M., Kidwell, J., \& Vrouwenvelder, J. S. (2016). Development and characterization of 3D-printed feed spacers for spiral wound membrane systems. Water Research, 91, 55-67. https:/ / doi.org/10.1016/j.watres.2015.12.052 Singh, G., \& Patidar, S. K. (2018). Microalgae harvesting techniques: A review. Journal of Environmental Management, 217, 499-508. https:/ / doi.org/10.1016/j.jenvman.2018.04.010

Su, Y., Song, K., Zhang, P., Su, Y., Cheng, J., \& Chen, X. (2017). Progress of microalgae biofuel's commercialization. Renewable and Sustainable Energy Reviews, 74, 402411. https:// doi.org/10.1016/j.rser.2016.12.078

Tan, W. S., Chua, C. K., Chong, T. H., Fane, A. G., \& Jia, A. (2016). 3D printing by selective laser sintering of polypropylene feed channel spacers for spiral wound membrane modules for the water industry. Virtual and Physical Prototyping, 11(3), 151-158. https://doi.org/10.1080/17452759.2016.1211925

Venault, A., Ballad, M. R. B., Huang, Y.-T., Liu, Y.-H., Kao, C.-H., \& Chang, Y. (2016). Antifouling PVDF membrane prepared by VIPS for microalgae harvesting. Chemical Engineering Science, 142, 97-111. https://doi.org/10.1016/j.ces.2015.11.041

Verma, N. M., Mehrotra, S., Shukla, A., \& Mishra, B. N. (2010). Prospective of biodiesel production utilizing microalgae as the cell factories: A comprehensive discussion. African Journal of Biotechnology, 9(10), 1402-1411. https://doi.org/10.5897/AJBx09.071 
Xu, H., Miao, X., \& Wu, Q. (2006). High quality biodiesel production from a microalga Chlorella protothecoides by heterotrophic growth in fermenters. Journal of Biotechnology, 126(4), 499-507. https://doi.org/10.1016/j.jbiotec.2006.05.002

Yanfen, L., Zehao, H., \& Xiaoqian, M. (2012). Energy analysis and environmental impacts of microalgal biodiesel in China. Energy Policy, 45, 142-151. https://doi.org/10.1016/j.enpol.2012.02.007

Yang, H.-L., Lin, J. C.-T., \& Huang, C. (2009). Application of nanosilver surface modification to RO membrane and spacer for mitigating biofouling in seawater desalination. Water Research, 43(15), 3777-3786. https:// doi.org/10.1016/j.watres.2009.06.002

Zhao, F., Chu, H., Su, Y., Tan, X., Zhang, Y., Yang, L., \& Zhou, X. (2016). Microalgae harvesting by an axial vibration membrane: The mechanism of mitigating membrane fouling. Journal of Membrane Science, 508, 127-135. https://doi.org/10.1016/j.memsci.2016.02.007

Zhao, F., Chu, H., Tan, X., Yang, L., Su, Y., Zhou, X., Zhao, J., \& Zhang, Y. (2016). Using axial vibration membrane process to mitigate membrane fouling and reject extracellular organic matter in microalgae harvesting. Journal of Membrane Science, 517, 30-38. https://doi.org/10.1016/j.memsci.2016.06.022

Zhao, F., Chu, H., Tan, X., Zhang, Y., Yang, L., Zhou, X., \& Zhao, J. (2016). Comparison of axial vibration membrane and submerged aeration membrane in microalgae harvesting. Bioresource Technology, 208, 178-183. https://doi.org/10.1016/j.biortech.2016.02.099 